\title{
On the diachronic development of $\mathrm{C}_{1} \mathrm{~V}_{1^{-}}$reduplication in some Austronesian languages
}

\author{
Lawrence A. Reid
}

Received: January 2008/Accepted: March 2009

(C) Springer Science+Business Media B.V. 2009

\begin{abstract}
This paper traces the diachronic developments of $\mathrm{C}_{1} \mathrm{~V}_{1}$ - reduplicative processes and their functions in some Austronesian languages. In the first half of the paper, we first examine the possible precursors of this reduplication, in particular the wide range of meanings that are associated with $\mathrm{C}_{1} \mathrm{~V}_{1^{-}}$- reduplication in Formosan languages. One of the issues that is addressed is the diachronic relationship of $\mathrm{C}_{1} \mathrm{~V}_{1^{-}}$reduplication to the fixed vowel reduplicative pattern, $\mathrm{C}_{1} a$-, that is commonly found in both Philippine and Formosan languages and which has been reconstructed for Proto-Austronesian. I will claim that the evidence suggests that this fixed vowel reduplicative pattern developed from $\mathrm{C}_{1} \mathrm{~V}_{1}$ - reduplication, and not the reverse. Various paths of semantic development are proposed which bridge the gap between iterative and other functions such as instrumental nominalization, human noun plurals and quantifiers. In the Philippines, the development of $* \mathrm{C}_{1} \mathrm{~V}_{1^{-}}$' human noun plural' in some of the northern languages of Luzon has resulted in the loss of any reduplicative tie to the base, resulting in the development of unique plural morphemes. This will be discussed in the second half of the paper, utilizing the concepts of abduction and deduction to demonstrate how reduplicative processes which are structurally ambiguous have been re-interpreted and analogically spread to affect lexical items originally not in the domain of the reduplication.
\end{abstract}

Keywords Reduplication · Fixed segment reduplication · Human noun plurals · Austronesian · Northern Philippine languages · Formosan languages · Ilokano · Bontok $\cdot$ Abductive innovation $\cdot$ Deductive innovation

\footnotetext{
L. A. Reid ( $ه)$

Department of Linguistics, University of Hawai'i at Mānoa, East-West Road, Moore Hall 569, Honolulu, HI 96822, USA

e-mail: reid@hawaii.edu
} 


\section{Introduction}

It is generally accepted by most linguists, archaeologists and other pre-historians, that Taiwan was the ancestral home of the Austronesian language family, and that all Austronesian languages outside of Taiwan constitute a single family of well over a thousand members, labeled here as Extra-Formosan (and commonly referred to in other literature as Malayo-Polynesian). Reduplicative processes in the Philippine languages then, are at least to some extent, probably inherited from ProtoExtra-Formosan (their immediate parent) and for some of the less-iconic functions that are found also in Taiwan appear to be cognate with similar reduplicative forms and functions in Formosan languages. Having said this, it is important to remember that it is impossible to show that highly iconic reduplications occurring in related languages - such as full reduplication functioning as an iterative verbal aspect-are reflexes of reduplicative processes reconstructible to their shared parent language (Proto-Austronesian, or Proto-Extra-Formosan, as the case may be) and are the result of inheritance rather than convergent development. By the same token, subsequent developments of full reduplication, such as various partial reduplicative patterns, and the common paths of semantic change that accompany them that are found in geographically remote but related languages, are probably not cognate with one another, but are the result of semantic developments of independent instances of iconic full reduplication, even though the forms being compared have lost any iconic sense.

It is therefore methodologically unwise to assume that even rare reduplicative forms and meanings apparently shared by widely separated languages in a family have the same status as cognates that is given to lexical items, or even to fixed segment (non-reduplicative) verbal or nominal affixes with relatable forms and meanings. As Blust (1998, p. 30) notes, the appearance of a reduplicative pattern in several languages of one family does not automatically point towards a common inheritance of the reduplicants, but can also be a product of convergence. Yet despite this proviso, as will be shown in Sect. 2.1 below, the tendency has been to reconstruct a reduplicative process, whenever similar forms and functions are found in languages belonging to different subgroups of the same family. ${ }^{1}$

Section 2 will provide a summary of the range of reduplicative processes which have been described for Formosan languages, from full reduplication to various partial reduplications including the ubiquitous $\mathrm{C}_{1} \mathrm{~V}_{1}$-form and finally the fixed segment, $\mathrm{C}_{1} a$-reduplication. It will claim, counter to various published analyses of the relationship between these forms, but in conformity with general principles of reduplicative reduction and grammaticalization processes, that $\mathrm{C}_{1} a$-reduplication is the end point of a development from $\mathrm{C}_{1} \mathrm{~V}_{1}$-reduplication, and not vice versa. Section 3 will examine the possible paths of semantic development which could have resulted in the use of $\mathrm{C}_{1} a$-reduplication as a marker of instrument nominalizations, and of $\mathrm{C}_{1} \mathrm{~V}_{1^{-}}$as a marker of plural human nouns. Section 4 will provide an account of the development of $* \mathrm{C}_{1} \mathrm{~V}_{1^{-}}$with the latter function in some of the Northern

\footnotetext{
${ }^{1}$ Blust (1998, p. 47) states 'Given this distribution, there can be no doubt that Ca- nominals were found in [Proto-Austronesian]'.
} 
Philippine languages which has resulted in the loss of the reduplicative tie to the base, and the development of unique plural morphemes. The processes by which these changes have taken place are explained as the result of instances of ambiguity, which have been analyzed differently from earlier generations and analogically extended to bases to which they would not otherwise apply, processes which have been labeled as abduction and deduction in the literature.

\section{Reduplicative patterns in Formosan languages}

In Formosan languages, a wide range of reduplicative patterns occur, ranging from full reduplication of disyllabic bases (with or without the coda of the second syllable), to various partial reduplications such as $\mathrm{C}_{1} \mathrm{~V}_{1} \mathrm{C}_{2} \mathrm{~V}_{2^{-}}, \mathrm{C}_{1} \mathrm{~V}_{1} \mathrm{C}_{2^{-}}, \mathrm{C}_{1} \mathrm{~V}_{1}$ :-, and $\mathrm{C}_{1} \mathrm{~V}_{1^{-}}$, alongside fixed vowel reduplications, such as $\mathrm{C}_{1} a$ - These patterns (and others), and their various functions are summarized in an article by Zeitoun and $\mathrm{Wu}$ (2006). Similar forms and functions occur in Philippine languages.

There are two opposing views that have appeared in the recent literature regarding the direction of change. The first, articulated by Blust (1998) with reference to fixed segment reduplication in Austronesian languages (specifically $\mathrm{C}_{1} a$-), is that partial reduplication (such as $\mathrm{C}_{1} \mathrm{~V}_{1^{-}}$), with the same functions, developed from $\mathrm{C}_{1} a$ - by a process he refers to as 'linguistic entropy', whether deriving numeral, verbal, or nominal forms $(1998$, p. 33). The second view contends that all partial reduplications result from normal processes of phonological erosion and assimilation from full reduplications (Bybee et al. 1994), and that fixed segment reduplications, such as $\mathrm{C}_{1} a-$, are the end result of changes affecting $\mathrm{C}_{1} \mathrm{~V}_{1}$-reduplications (Niepokuj 1997). While Bybee's and Niepokuj's claims that partial reduplications are always the result of developments from full reduplication are argued against by Hurch and Mattes (2005), all agree that fixed segment reduplications, such as $\mathrm{C}_{1} a$-, develop diachronically from $\mathrm{C}_{1} \mathrm{~V}_{1}$-reduplications, and not the reverse.

\subsection{Was fixed vowel reduplication the source for $\mathrm{C}_{1} \mathrm{~V}_{1}$ - reduplication?}

In a wide-ranging paper on $\mathrm{C}_{1} a$ - reduplication in Austronesian languages, Blust (1998, p. 30) reconstructs this form to Proto-Austronesian, with three unrelated functions, "(1) the formation of a derivative set of numerals used in counting humans, (2) the formation of certain verb forms, and (3) the formation of instrumental nouns." ${ }^{2}$ In effect, he reconstructs three distinct reduplicative prefixes of the shape ${ }^{*} \mathrm{C}_{1} \mathrm{a}$-, in that he claims that the functions are unrelated. He further notes that, "[I]n several cases, Ca- reduplication apparently has evolved into CV-reduplication, thereby losing some of the markedness that makes it important for purposes of historical inference. As will be seen, this tendency is manifest not only with the

\footnotetext{
${ }^{2}$ A subsequent paper by Blust (1999, p. 169) however, claims Proto-Austronesian status for only two of these functions. Although noting the use of $\mathrm{C}_{1} a$ - for forming certain verb forms, such as durative aspect, and other functions in Thao, he considers that these are innovative developments in Austronesian languages, "exploiting" the form he reconstructs to Proto-Austronesian.
} 
numerals, but also in other lexical domains. A similar loss of distinctiveness is found in the domain of semantics, where $\mathrm{Ca}$ - reduplication to form instrumental nouns evidently was generalized to a larger and more diffuse lexical class in languages such as Balinese" (1998, p. 33).

Blust outlines the different verbal functions of $\mathrm{C}_{1} a$ - reduplication in the Formosan languages Mayrinax Atayal, Thao, Tanan Rukai and Puyuma, noting that these include various aspectual meanings such as durative, iterative, progressive, continuous, repetitive, or future. He also includes examples from Tetun in East Timor, where $\mathrm{C}_{1} a$-reduplication also marks durative, repeated action, or plurality. He then cites Rukai (a Formosan language) and Tagalog (a Philippine language) as showing $\mathrm{C}_{1} \mathrm{~V}_{1}$ - reduplication to mark future or contemplated aspect, claiming that these, too, developed from fixed segment reduplication, a claim that is echoed in Mattes (2007, p. 83) for Bikol.

A closer look at the Rukai and Tagalog data however, suggests a different story. According to Hsin (1996), cited in Zeitoun and Wu (2006, p. 113), stem reduplication in Maga Rukai is not simply $\mathrm{C}_{1} \mathrm{~V}_{1^{-}}$, but subsumes two subpatterns " $\mathrm{CV}$ - and $\mathrm{CVC}$ reduplication. $\mathrm{CV}$ - reduplication consists of the reduplication of the first syllable.... CVC- involves the reduplication of the first syllable CVC-, or the first syllable along with the first consonant of the second syllable CV.C-." When occurring on verbs, the functions of these reduplicative patterns include intensification of the degree of stative verbs, and repetitive/continuative action in dynamic verbs.

Blust's claim (2003, p. 468) that "Tagalog marks the future of dynamic verbs through CV-reduplication" is incorrect. In Tagalog, there are two monosyllabic, reduplicating prefixes. One, $\mathrm{C}_{1} \mathrm{~V}_{1^{-}}$, marks repetitive activity, it always has a short vowel. The other, $\mathrm{C}_{1} \mathrm{~V}_{1}$ :-, marks incomplete or contemplated activity (Blust's "future"), and always has a long vowel, whatever the length of the vowel in the following syllable. Compare, for example, the aspectual reduplicating prefix /la:/ in /nagla:lakbay/ 'is traveling', /magla:lakbay/ 'will travel', and the stem-forming reduplicating prefix /la/ in /maglalakbay/ 'travel (repeatedly etc.)' (Schachter 1987). Blust's claim apparently refers to the latter of the two Tagalog reduplications, being unaware of the vowel length distinction. An explanation for the source of the vowel length in Tagalog is provided in Reid (1992, p. 78) and claims that such forms developed from distinct reduplicative patterns in the parent of the Philippine languages. $\mathrm{C}_{1} \mathrm{~V}_{1}$ :- reduplication in Tagalog apparently developed from $* \mathrm{C}_{1} \mathrm{~V}_{1} \mathrm{C}_{2^{-}}$ 'imperfective' reduplication, as found also in many northern Philippine languages, such as Ilokano and Bontok (and also in Rukai). Since $C_{2}$ in many $C_{1} V \cdot C_{2} V_{3}$ bases is glottal stop, and when reduplicated with $\mathrm{C}_{1} \mathrm{~V}_{1} \mathrm{C}_{2^{-}}$would result in Tagalog in a disallowed - $\mathrm{PC}$ - word medial sequence, such sequences were resolved by glottal stop syncope and compensatory lengthening of the reduplicated vowel, a process found also in Ilokano in which $\mathrm{C}_{1} \mathrm{~V}_{1}$ :- occurs on glottal stop medial bases, while $\mathrm{C}_{1} \mathrm{~V}_{1} \mathrm{C}_{2^{-}}$occurs on bases with some medial consonant other than glottal stop (see examples in (20), below). In Tagalog, geminate clusters which would have resulted when $\mathrm{C}_{1}$ and $\mathrm{C}_{2}$ of a base are the same consonant were also disallowed. So Tagalog, like some other Central Philippine languages, has generalized $\mathrm{C}_{1} \mathrm{~V}_{1}$ :- to all environments where earlier $\mathrm{C}_{1} \mathrm{~V}_{1} \mathrm{C}_{2^{-}}$was required. An alternate development of $\mathrm{C}_{1} \mathrm{~V}_{1} \mathrm{C}_{2}$ - which produces $\mathrm{C}_{1} \mathrm{~V}_{1}$ - on some bases occurs in Bontok, one of the Central 
Cordilleran languages of northern Luzon. In this language, when $\mathrm{C}_{2}$ is a glottal stop, a glide, or a liquid, the medial consonant is copied as a glottal stop. This also results in an unallowable - $\mathrm{PC}$ - sequence, but is resolved not by syncope and vowel lengthening as in Tagalog and Ilokano, but by metathesis, as in $* \mathrm{C}_{1} \mathrm{~V}_{1} \mathrm{C}_{2}$-dá?it $>* *$ da?dá?it $>$ /dad?á?it/ [tfad?á?it] chad-áit 'is sewing'; * $\mathrm{C}_{1} \mathrm{~V}_{1} \mathrm{C}_{2}$-kawðl > **ka?kawðl > /kak?awál/ [kak?awós] kak-awer 'is embracing'; * $\mathrm{C}_{1} \mathrm{~V}_{1} \mathrm{C}_{2}$-layáw > *la?layáw > /lal?ayáw/ [la.iayáw] lar-ayaw 'is fleeing' (Reid 1976; Thurgood 1997).

Looking now at the different reduplicative patterns in Formosan languages included in Zeitoun and $\mathrm{Wu}$ (2006), which express aspectual meanings such as iterative, progressive, and semantically related meanings, we find three of the languages cited earlier by Blust as having $\mathrm{C}_{1} a$ - reduplication, shown in (1), with the reduplicative morpheme in bold font.

(1) $\mathrm{C} a$ - reduplication

Rukai ("progressive aspect or irrealis mood"), e.g., $k<e m>a s u$ 'bring', $\boldsymbol{k}<$ em $>\boldsymbol{a}$-kasu 'is bringing'; $\boldsymbol{k a}$-kasu 'will bring'

Amis ('continuous/repetitive aspect') mi-rosaros 'saw', mi-ra-rosaros 'keep sawing'

Thao ('continuous/repetitive aspect') $k<m>$ iskis 'press down', $\boldsymbol{k}<m>\boldsymbol{a}$-kiskis keep pressing down'

In addition, a wide range of reduplicative patterns from full reduplication to single consonant reduplication can also express the same aspectual meanings, not just the $\mathrm{C}_{1} \mathrm{~V}_{1^{-}}$that Blust claims developed from $\mathrm{C}_{1} a$-. These are shown in (2)-(9).

(2) $\operatorname{CVCV}(\mathrm{C})$ - reduplication

Amis ('continuous/repetitive aspect') temok, 'have palpitation', temok-temok keep on having palpitation'

Isbukun Bunun ('progressive') 'ama 'carry on back', 'ama-'ama 'be carrying on back'

Paiwan ('continuous/repetitive aspect') $l \boldsymbol{r}<$ em $>$ elay 'mend', $\boldsymbol{l r}<$ em $>$ ela-lrelay 'be mending'

Mantauran Rukai ('continuous/repetitive aspect') o-lrodho 'mix', o-lrodholrodho 'keep on mixing'

(3) CV:- (represented as CVV-) reduplication

Pazeh ('progressive aspect') bazu' 'wash', baabazu' 'be washing'

Saisiyat ('continuative aspect') $k<o m>a$.at 'write', $\boldsymbol{k a \boldsymbol { a }}$ - $k a$ at 'keep on writing'

(4) CVV- reduplication

Mantauran Rukai ('continuative/repetitive aspect') $o$-dhodho'o 'pour water', o-dhoo-dhodho'o 'often pour water'

Thao ('continuative/repetitive aspect') mi-dauk 'be still', mi-dau-dauk 'keep still'

(5) CVC- reduplication

Puyuma ('continuative/repetitive aspect') pespes 'massage', pes-pespes-ay 'he kept on massaging (him)' 
Maga Rukai ('continuative/repetitive aspect') te-s-damraa 'cook side dishes', te-s-dam-damraa 'keep on cooking side dishes'; ap-baka 'speak', ap-bak-baka 'keep on speaking'

Saisiyat ('continuative aspect') bilith 'touch', bil-bilith 'keep on touching'

Tsou ('repetitive aspect') mahfo 'take', mah-mahfo 'take many times'

(6) $\mathrm{CV}(\mathrm{C})-$ reduplication

Isbukun Bunun ('continuative/repetitive aspect') lunghu 'rest', lu-lunghu 'keep on resting'; ma-pinkaylas 'wake s.o. up', ma-pin-pinkaylas 'often wake s.o. up'

(7) $\mathrm{C}(\mathrm{C}) \mathrm{V}$ - reduplication

Maga Rukai ('continuative/repetitive aspect') o-drngədrngə 'dry', o-drngədrngədrngə

(8) CV-reduplication

Pazeh ('continuative/repetitive aspect') mu-bizu' 'write', bi-bizu' 'be writing'

(9) C- reduplication

Squliq Atayal ('continuative/repetitive aspect') n-buw 'drank', $\boldsymbol{b}$-n-buw 'would drink'

\subsection{Loss of phonological structure by grammaticization}

In their study of the evolution of tense, aspect and modality systems, Bybee et al. (1994) discuss the evolutionary paths of reduplicative patterns. They state:

We consider it entirely plausible that partial reduplications result from the phonological erosion and assimilation of totally reduplicated forms. Of course, once a partial reduplication pattern becomes well established in the language, it can become productive and extend to new forms, such as loanwords. However, we would contend that the original source of such reduplications is in total repetition of the verb... [O] ur theory would predict that total reduplication expresses the earlier, fuller meaning of reduplication, while partial reduplications express more general meanings and meanings that occur later on the evolutionary path... total reduplications express the most specific meanings, while partial reduplications express more general meanings or have a greater variety of uses or functions. (1994, p. 169)

They tested their theory against a limited set of languages, but were able to show that the most common sense of full reduplicative patterns were maximally iconic, with iterative, continuative or frequentative meanings, while partial reduplications more typically expressed senses that developed from them, such as distributive/ plural, or habitual meanings.

Niepokuj (1997) in a more detailed account of the development of reduplicative systems, stemming from her 1991 doctoral dissertation, extends her analysis to systems such as are found in Formosan languages, where partial reduplication exists in languages side-by-side with fixed segment reduplication. She claims that: 
[A] strong developmental tendency exists in one direction only: toward fixedvowel reduplication. ... In most or all of the cases examined in which both vowel-copying and fixed-vowel reduplication exist in the same language or in the same language family, the evidence points to the vowel-copy reduplication being older and the fixed-vowel reduplication being younger. (1997, p. 41)

Niepokuj's explanation is that "in initial position the vowel is of relatively less importance in establishing a connection between two morphemes... [and thus] the vowel is available to convey morphological regularity: that is, it provides a site which can be used as consistent phonological representation of a consistent semantic value... Reduplicated affixes must tread a fine line between expressing a consistent phonetic value and resembling their base as much as possible. Developing a fixed vowel is one way of balancing these two conflicting goals" (1997, pp. 41-42).

That the fixed vowel should be $a$ in reduplicants that developed from $\mathrm{C}_{1} \mathrm{~V}_{1^{-}}$- in Austronesian languages is hardly surprising. There are at least two probably related explanations. The first is that /a/ is the most common vowel in the first syllable of disyllabic roots in Austronesian languages, and is therefore the most frequent vowel in initial reduplicated syllables, and could be expected to be analogically extended to form a fixed vowel reduplicating pattern. The second, and probably the most important, is that the great majority of monosyllabic prefixes in Austronesian languages have /a/ as their vocalic nucleus, including $p a-, m a-, k a-, s a-$, and $t a-$, each of which has multiple functions (Blust 2003), and thus provide a strong basis for analogical extension from $\mathrm{C}_{1} \mathrm{~V}_{1}$ - to $\mathrm{C}_{1} a$-.

There are at least two other cases of fixed vowel reduplication in Philippine languages, beyond the Sangir and Bolaang Mongondow cases discussed by Blust (1997, pp. 41-45). One is a $C_{1} a$ - pattern found in Central Cagayan Agta (Healey 1960, p. 9) which, unlike its function in other languages, marks plural actors, e.g., mag-welwel 'scold', mag-wa-welwel kid 'they are all scolding (him)', and corresponds to, and I would claim, developed from the $\mathrm{C}_{1} \mathrm{~V}_{1^{-}}$- pattern found in other Philippine languages marking verbs with multiple actors either reciprocal or in simultaneous action, to be discussed below. The other case of fixed vowel reduplication is Botolan Sambal $\mathrm{C}_{1} a w$ - which functions to pluralize nouns, e.g., lapis 'pencil', lawlapis 'pencils', dowih 'thorn', dawdowih 'thorns' (Antworth 1979, p. 9). The same fixed-vowel reduplicant is also found in Tausug (and in neighboring Yakan, one of the Sama-Bajaw languages, as $\mathrm{C}_{1} e w$-), with multiple functions. In Tausug it is usually used to form distributive verbs in which many arguments are affected or involved. However, with single arguments, this affix can also be iterative, intensive, or durative, e.g., mahawhulug 'fall scattered, strewn' (hulug 'fall'), magtawtangis 'keep crying' (tangis 'cry'), etc. When used with some kin terms (and human nouns), it forms collectives, e.g., maas 'old; parent', mawmaas 'parents; older relatives', bangsa 'people, nation', kabawbangsahan 'whole nation, all the citizens' (Rubino 2006, p. 275). ${ }^{3}$

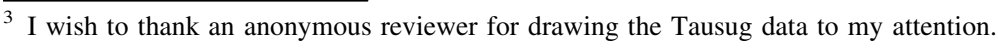




$$
\begin{aligned}
& >\mathrm{C}_{1} a \mathrm{C}_{2^{-}}>\mathrm{C}_{1} a C_{-} \\
\mathrm{C}_{1} \mathrm{~V}_{1} \cdot \mathrm{C}_{2} \mathrm{~V}_{2}(\mathrm{C})->\mathrm{C}_{1} \mathrm{~V}_{1} \cdot \mathrm{C}_{2} \mathrm{~V}_{2^{-}}>\mathrm{C}_{1} \mathrm{~V}_{1} \mathrm{C}_{2^{-}} & >\mathrm{C}_{1} \mathrm{~V}_{1^{i^{-}}}>\mathrm{C}_{1} \mathrm{~V}_{1^{-}}>\mathrm{C}_{1} a- \\
& >\mathrm{C}_{1} V \mathrm{C}_{2^{-}}
\end{aligned}
$$

Fig. 1 Development paths of reduplicative patterns

$$
\begin{aligned}
& \text { ITERATIVE }>\text { CONTINUATIVE }>\text { PROGRESSIVE } \\
& \text { ITERATIVE }>\text { FREQUENTATIVE }>\text { HABITUAL }
\end{aligned}
$$

Fig. 2 Development paths of reduplicative semantics (1) (Bybee et al. 1994, p. 172)

Other three segment fixed vowel reduplicative patterns are reported by Bowden (cited in Blust 1998, p. 49) for some south Halmahera languages. In these cases, $\mathrm{C}_{1} \mathrm{~V}_{1} \mathrm{C}_{2^{-}}, \mathrm{C}_{1} a \mathrm{C}_{2^{-}}$, or $\mathrm{C}_{1} V \mathrm{C}_{2^{-}}$(where $V$ represents some fixed vowel other than $a$ ), all of which function as instrumental noun derivation or some similar meaning, are considered by Blust to have developed from his Proto-Austronesian ${ }^{*} \mathrm{C}_{1} a$ - (Blust 1998, p. 50). However, in my view, an alternative interpretation which has the fixed vowel reduplicative patterns of Botolan Sambal and the South Halmahera languages developing independently from $\mathrm{C}_{1} \mathrm{~V}_{1} \mathrm{C}_{2^{-}}$or $\mathrm{C}_{1} \mathrm{~V}_{1^{-}}$- patterns seems much more convincing.

Possible paths of formal development (where $V$ represents a fixed vowel, and $C$ represents a fixed consonant, as in Botolan Sambal and Tausug $\mathrm{C}_{1} a w$-) are shown in Fig. 1.

\section{From iconic to non-iconic semantic development}

In this section we examine the possible paths of semantic development which could have resulted in the use of $\mathrm{C}_{1} \mathrm{~V}_{1}$ - as a marker of plural human nouns and quantifiers, and of $\mathrm{C}_{1} a$ - reduplication as a marker of instrument nominalizations. Such noniconic functions although apparently unrelated, can be shown to be points along paths of semantic change that have their source in iconic reduplication. Bybee et al. (1994, p. 172) proposed paths of semantic change beginning with iconic iterative senses progressing to the marking of intransitive verbs in some of the Austronesian languages of Oceania, as shown in Fig. 2.

Similar paths of semantic change developing from the original iconic marking of iterative verbs can be shown to result in the marking of plural human nouns and subsequently to the marking of plural human demonstratives and human quantifiers. Frequentative aspect on verbs that can be performed on more than one occasion across time or space can be interpreted as distributive. Since such verbs typically expect plural human agents, one path of development is to mark verbs with more than one agent acting either in a reciprocal or reflexive way (as in (10)a), or in cooperation with others (as in (10)b, and (11)a-b), shown in Fig. 3.

(10) Batad Ifugao (Newell 1993, pp. 53-54).

a. hinhohōod da Uwek 'ay Damānay each.REFL.wait PL Uwek and Damānay

'Uwek and Damānay waited for each other.' 


\section{b. ' $a h i=d a \quad$ tatapeng \\ together=3PL PL.build.stone.retaining.wall \\ 'They all build stone retaining walls'}

In 'Philippine-type' languages, any so-called 'actor-voice' verb can follow a nominal specifier (often labeled as a "determiner") and be derived as a nominal with meanings such as 'the ones who perform the action of the verb'. Examples (11) $\mathrm{a}-\mathrm{b}$ illustrate $\mathrm{C}_{1} \mathrm{~V}_{1}$ - on 'non-actor voice' verbs with distributive meaning, while in (11)c-d, 'actor-voice' verbal forms with $\mathrm{C}_{1} \mathrm{~V}_{1}$ - follow nominal specifiers and are derived as plural human nouns.

\section{Khinina-ang Bontok}
a. ipipilit nan tap- $i=n$ si $\operatorname{amam-a} \ldots$
PL.insist SPEC PL.other=GEN SPEC PL.married.man
'The rest of the married men insist ...'
b. aagtowen $=$ cha nan makan
PL.carry.on.head=3PL SPEC cooked.rice
'They carry the cooked rice on their heads.'
c. iyali=n nan ninsasangfo nan fotog
bring $=$ GEN SPEC AV.PL.do.pig.sacrifice SPEC pig
'The ones performing the pig sacrifice bring the pig.'
d. en = cha ayakhan nan omaator ay iTongfar
go=3PL call SPEC AV.PL.reside.men's.house LG person.Tongfar 'They go call the men from the Tongfar men's group house.'

From its occurrence in nominalizations referring to plural human agents, the reduplication could be extended to non-derived nominals to mark plural human nouns, whether agents of verbs or not. Once divorced from their original verbal context, the reduplications could then be extended to derive a third person plural demonstrative pronoun (in Amis, Reid 2007, p. 245), quantifiers and numerals referring specifically to humans (Blust 1998, 1999) and eventually to general (that is non-human) plural nouns, as shown in Fig. 4.

Another path of semantic change which apparently developed from the frequentative aspect of verbs, results in instrumental nominalizations of verbs. With verbs, such as 'comb', 'sweep', 'cut', 'chop', etc., that require the repeated use of an

$$
\begin{aligned}
& >\text { REFLEXIVE } \\
\text { ITERATIVE }>\text { DISTRIBUTIVE }>\text { PL HUMAN AGENT } & >\text { COOPERATIVE } \\
& >\text { RECIPROCAL }
\end{aligned}
$$

Fig. 3 Development paths of reduplicative semantics (2)

$\begin{aligned} & >\text { PL HUMAN DEMONSTRATIVE } \\ \text { ITERATIVE }>\text { DISTRIBUTIVE }>\text { PL HUMAN AGENT }>\text { PL HUMAN NOUN }>\text { HUMAN QUANTIFIERS } & >\text { GENERAL PLURAL }\end{aligned}$

Fig. 4 Development paths of reduplicative semantics (3) 
Fig. 5 Development paths of reduplicative semantics (4)

instrument for their performance, it is not surprising that the reduplication that first marked their frequentative nature became associated with the non-human agent, or instrument, with which these verbs are performed. In 'Philippine-type' languages, such verbs could also freely be derived as nominals meaning 'the instrument by which the action of the verb is performed'. Such forms are described by Blust (1998, p. 37) as 'canonical instruments'. Once divorced from their original verbal context, the reduplications could then be extended to derive what Blust refers to as "noncanonical instruments', such as body-parts (1998, p. 38), as shown in Fig. 5.

\section{The development of $* \mathrm{C}_{1} \mathrm{~V}_{1}$ - 'human noun plural' in some Northern Luzon languages}

In Reid (2006) evidence was presented suggesting that the presence of $* \mathrm{C}_{1} \mathrm{~V}_{1}$ - to derive human noun plurals in many of the northern languages of the Philippines implied that this reduplicative process was probably present in their immediate proto-language, Proto-Northern Luzon, and was possibly also in its immediate parent, Proto-Extra Formosan. ${ }^{4}$ In a number of languages the form can be shown to be productive, in that it functions to pluralize human nouns of Spanish or English origin (such as Ilokano papadi 'priests', cf. kakabsat 'siblings', and Bontok popolis 'policemen'). In some languages it also includes some body part nouns (Bontok lilima 'arms' and sisikí 'legs'), and has extended its function further to derive plurals of terms associated with humans, such as human characteristics (Balangao babasol 'sins'), domestic furniture (Balangao tutu?du 'chairs'), domestic animals (Inibaloi mamanuk 'chickens'), domestic plants (Pangasinan ninióg 'coconuts'), and for locales associated with human activity (Kalinga boboloy 'village', cf. boloy 'house', Balangao ?u ?uma 'fields'). While the pluralization of such nouns in each of these languages is optional (common nouns in Philippine languages are generally unmarked for number), when the reduplication derives plural kinship terms, such as

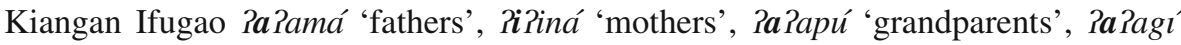
'kin (PL)', etc., the derivation is generally obligatory.

In this section, an account will be given of the development of $* \mathrm{C}_{1} \mathrm{~V}_{1}$ - in some of the Northern Philippine languages which has resulted in the loss of the reduplicative tie to the base, and the development of unique plural morphemes. Several sets of data which illustrate this phenomenon are given in (12) and (13) below. A cursory morphological analysis of this data would suggest that the plural of human nouns in Ilokano is formed by geminating the second consonant of the singular form, while in Bontok, human nouns which begin with a glottal stop are pluralized by insertion of a glottal stop infix following the second consonant of the singular form. However it

\footnotetext{
${ }^{4}$ Chamorro, probably an isolate of Proto-Extra-Formosan, shows at least the form lahi 'man, male, boy', la lahi 'men, males, boys' (Topping et al. 1975). An anonymous reviewer notes that Malagasy also has lahy vs. lelahy.
} 
can be shown that the plural forms in both languages were originally derived by the addition of a reduplicative $\mathrm{C}_{1} \mathrm{~V}_{1^{-}}$prefix to the singular form.

(12) Ilokano (Vanoverbergh 1955, p. 51)

babári / babbá?i 'woman' / 'women'

(13) Khinina-ang Bontok

$\begin{array}{llll}\text { Pamá } & \text { / Pam?á } & \text { 'father' } & \text { / 'fathers' } \\ \text { Piná } & \text { / Pin?á } & \text { 'mother' } & \text { / 'mothers' } \\ \text { Papú } & \text { / Pap?ú } & \text { 'grandparent' } & \text { / 'grandparents' } \\ \text { Panák } & \text { / Pan?ák } & \text { 'child' } & \text { / 'children' } \\ \text { Pətád } & \text { / Pət?ád } & \text { 'sibling } & \text { / 'siblings' }\end{array}$

The processes which have brought about these changes are characterized in this paper as abduction and deduction.

\subsection{Abduction and deduction}

The Oxford companion to philosophy defines ABDUCTIVE reasoning as follows: "Abductive reasoning accepts a conclusion on the grounds that it explains the available evidence." In his classic work on processes of phonological change, Andersen (1973) utilized the concept to characterize innovations that take place in phonology where input data are ambiguous and are analyzed differently from the way the data are analyzed in the source. Deutscher (2002, p. 482) characterizes abduction as "the conceptual leap from data to an explanatory hypothesis," claiming also that in language change, "an abductive innovation is simply REANALYSIS", a term which he defines as a "change in the underlying structure of an utterance which does not involve modifications on the surface... it is the attribution of a 'wrong analysis' to a surface utterance" (2002, p. 482). This is an unfortunate definition, in that abduction is the process by which all children build their internalized grammars, and although, from a linguist's point-of-view, it often results in structures that are different from those of earlier generations, the child is not reanalyzing anything, and certainly is not coming up with 'wrong analyses'. Where ambiguity is involved, a different analysis may be chosen from that of earlier generations, resulting in language change. Andersen's (2006, p. 254) definition is much better: "Reanalysis: The fresh analysis of received usage in the course of new speakers' grammar formation.”

DEDUCTIVE reasoning, as described by Deutscher (2002, p. 483), occurs when "An existing grammatical rule is used in a context where it was not used before. Extension (or 'analogical extension') is just the same: it is the process in which an existing linguistic rule is extended from a more restricted context to a less restricted one. By definition, then, any 'deductive innovation' is necessarily an instance of 'extension'."

Analogy is a key factor, not only in deductive innovation, but also in abduction itself, as Fischer (2007, p. 47) notes, citing McMahon's (1994, p. 122) description of 
the relation between abduction and analogy as follows: '. . .one way of implementing analogical change is innovation by children using abductive reasoning.' But it is in the deductive process that analogy becomes apparent, when forms that were previously unaffected have the 'fresh analysis' applied to them and 'actualization' of the change takes place (Andersen 2001).

\subsection{Innovations in the marking of plural human nouns}

In this section, data from Ilokano and Bontok, two of the Northern Luzon languages will be examined to demonstrate how ambiguity can result in abductive innovations quite distinct from those of earlier generations.

\subsubsection{Ilokano human noun plurals}

In Ilokano, while many human nouns continue to be formed by $\mathrm{C}_{1} \mathrm{~V}_{1}$ - reduplication, other human nouns are pluralized by processes which developed from $\mathrm{C}_{1} \mathrm{~V}_{1^{-}}$reduplication. Prominent among such forms are those shown in (12) above. The historical process by which such forms developed is shown in (14). It should be noted that the singular forms for 'man' and 'woman' are already reduplicated with a non-productive $\mathrm{C}_{1} \mathrm{~V}_{1^{-}}$prefix, the base forms bá?i and láki meaning respectively 'female' and 'male', of non-human animals. ${ }^{5}$

(14) Ilokano

$$
\begin{array}{llll}
{ }^{*} \mathrm{C}_{1} \mathrm{v}_{1} \text { - babá?i }=* \text { bababá?i } \rightarrow \text { babbá?i } & \text { 'women' } & \text { (cf. babáPi 'woman') } \\
{ }^{*} \mathrm{C}_{1} \mathrm{v}_{1} \text { - laláki }=* \text { lalaláki } \rightarrow \text { lalláki 'men' } & \text { (cf. laláki 'man') }
\end{array}
$$

Note that loss of an unstressed /a/ is not a regular sound change in Ilokano, but does occur in environments associated with reduplication resulting in geminate consonant clusters, a case of anti-antigemination, i.e., a phonological process resulting in syncope only between identical consonants that appears to violate the supposed phonological constraint on gemination (Odden 1988; Blust 2007). The addition of the plural $C_{1} V_{1}$ - reduplication creates a reduplicative substring $C_{1} V_{1} C_{1} V_{1}$ - in which the final vowel is unstressed. This is precisely the environment described by Blevins (2005, p. 519), in which word-internal phonological predictability may result in vowel loss.

Given the surface forms in (12), children forming their own grammars appear to have the option of assuming either that the plural forms are composed of $\mathrm{C}_{1} \mathrm{~V}_{1^{-}}$reduplication, and that a phonological rule deletes the unstressed vowel between the second and third identical consonants, or they may assume that the second consonant of the singular form is simply geminated to form the appropriate plural. These can be represented by the following statements.

\footnotetext{
5 Cognates with $\mathrm{C}_{1} \mathrm{~V}_{1}$ - reduplication are found in many Philippine languages, e.g., Tagalog lalaki 'man', babae 'woman' (Lopez 1949). Some Formosan languages also show probable cognates with $\mathrm{C}_{1} \mathrm{~V}_{1^{-}}$ reduplication for 'woman', e.g., Rukai Pababái, Paiwan vaváyan, and Amis fafahi'án (Ferrell 1969). The reduplicated form has been reconstructed to Proto-Austronesian (Zorc 1979, p. 30).
} 
Abductive Innovation: Hypothesis 1

"Human nouns are pluralized by reduplicating $\mathrm{C}_{1} \mathrm{~V}_{1^{-}}$and then deleting an unstressed vowel in the following syllable."

\section{Abductive Innovation: Hypothesis 2}

"Human nouns are pluralized by geminating the second consonant."

Since there is no way to directly access a child's analysis, we can determine it only by finding instances where the rule has been applied by deductive extension to forms that would not otherwise have been affected.

Ilokano has a set of human nouns which begin with the sequences /ba/ and /la/, forms which we could expect to be treated analogically in the same manner as the words for 'man' and 'woman'. These are shown in (15), with their plural forms. It is clear first, that they are not formed simply by reduplicating $\mathrm{C}_{1} \mathrm{~V}_{1^{-}}$and second, that neither of the above hypotheses were applied for their formation. Under Hypothesis 1 , for example, the forms shown in (16) would be grammatical, while under Hypothesis 2, those shown in (17) would be.

(15) Ilokano (Vanoverbergh 1955, p. 51)

$\begin{array}{llll}\text { barú } & \text { / babbarú } & \text { 'unmarried man' } & \text { / 'unmarried men' } \\ \text { balásang } & \text { / babbalásang } & \text { 'unmarried woman' } & \text { / 'unmarried women' } \\ \text { bakét } & \text { / babbakét } & \text { 'old woman' } & \text { / 'old women' } \\ \text { lakáy } & \text { / lallakáy } & \text { 'old man' } & \text { / 'old men' }\end{array}$

(16) Ilokano (applying Hypothesis 1) ${ }^{6}$

$\begin{array}{llll}\text { barú } & / \text { *babru } & \text { 'unmarried man' } & \text { / 'unmarried men' } \\ \text { balásang } & / \text { *bablásang } & \text { 'unmarried woman' } & \text { / 'unmarried women' } \\ \text { bakét } & / \text { *babkét } & \text { 'old woman' } & \text { / 'old women' } \\ \text { lakáy } & / \text { *lalkáy } & \text { 'old man' } & \text { / 'old men' }\end{array}$

(17) Ilokano (applying Hypothesis 2)

$\begin{array}{llll}\text { barú } & / \text { *barru } & \text { 'young man' } & \text { / 'young men' } \\ \text { balásang } & \text { / *ballásang } & \text { 'young woman' } & \text { / 'young women' } \\ \text { bakét } & \text { / *bakkét } & \text { 'old woman' } & \text { / 'old women' } \\ \text { lakáy } & \text { / *lakkáy } & \text { 'old man' } & \text { / 'old men' }\end{array}$

It appears that a third analysis of the 'man/woman' forms has been assumed, based not on the reduplicated singular forms baba'i and laláki, but on their plural forms, babbaîi and lallaki, respectively.

\section{Abductive Innovation: Hypothesis 3}

"Human nouns are pluralized, like 'men' and 'women', by $\mathrm{C}_{1} \mathrm{~V}_{1}$ - reduplication and gemination of the initial consonant of the (unreduplicated) base."

\footnotetext{
6 The asterisk before the forms in these examples indicates that they are non-occurring.
} 
The possibility that there is some factor other than analogical extension at work here was considered. Blevins (2004, p. 174) notes that one of the sources of gemination is lengthening under stress, or post-tonic gemination. In each of the examples in (15), the vowel preceding the geminate consonant, although not carrying primary stress, does carry secondary stress, and might result in gemination of the following consonant. However (18) follows the same reduplicative pattern (even though the initial consonant is not $/ \mathrm{b} /$ or $/ \mathrm{l} /$ ), but the vowel in the reduplicant is unstressed.

(18) Ilokano (Vanoverbergh 1955, p. 51)

tá?u / tattá?u 'person' / 'people'

While Hypothesis 2 does not appear to be the basis for any of the forms given above, it does appear to be the basis for the formation of plural human nouns beginning with glottal stop.

Abductive Innovation: Hypothesis 2'

"Human nouns (beginning with glottal stop) are pluralized by geminating the second consonant."

(19) Ilokano (Vanoverbergh 1955, p. 51; Rubino 2000, p. 231)

$\begin{array}{llll}\text { Pamá } & \text { / Pammá } & \text { 'father' } & \text { / 'fathers' } \\ \text { Piná } & \text { / Pinná } & \text { 'mother' } & \text { / 'mothers' } \\ \text { Papú } & \text { / Pappú } & \text { 'grandchild' } & \text { / 'grandchildren' } \\ \text { Panák } & \text { / Pannák } & \text { 'child (kin)' } & \text { / 'children' } \\ \text { Pasáwa } & \text { / Passáwa } & \text { 'spouse' } & \text { / 'spouses' } \\ \text { Pubíng } & \text { / Pubbíng } & \text { 'child (age)' } & \text { / 'children' } \\ \text { (ka)?arúba } & \text { / (ka)Rarrúba } & \text { 'neighbor' } & \text { / 'neighbors' }\end{array}$

This abductive innovation is apparently built by analogy on the full, reduplicated forms for 'woman' and 'man', and the fact that many other human nouns have their second consonant geminated. Note also that if Hypothesis 3 were correct, it would produce geminate sequences of glottal stop that are phonologically disallowed in Ilokano, such as *?a??amá 'fathers', etc.

How do we know that gemination in the plurals of glottal stop initial human nouns is the result of an abductive innovation, rather than the result of regular phonological changes following $\mathrm{C}_{1} \mathrm{~V}_{1}$ - reduplication? Could the gemination be the result of consonant cluster assimilation (Blevins 2004, p. 171) following medial vowel syncope, so that, for example, ${ }^{*} \mathrm{C}_{1} \mathrm{~V}_{1}$-Pamá $=$ ?a?amá $\rightarrow$ ?a?má $\rightarrow$ Ramma? Other Ilokano data suggest that consonant cluster assimilation involving sequences with an initial glottal stop does not occur. As noted in Sect. 2.1, such sequences result rather in loss of glottal stop with lengthening of the preceding vowel. In (20)a, the reduplicant $\mathrm{C}_{1} \mathrm{~V}_{1} \mathrm{C}_{2}$ - on verbs conveys continuative aspect, while on pronouns it has a restrictive sense, and on non-human, common nouns it is plural or distributive (Benton 1974-1975). Whatever its function, when $\mathrm{C}_{2}$ of the base is a glottal stop (as in (20)b), the reduplicant surfaces as $C_{1} V_{1}$ :-, regardless of the stress pattern of the base. 
(20) Ilokano (Rubino 2000)

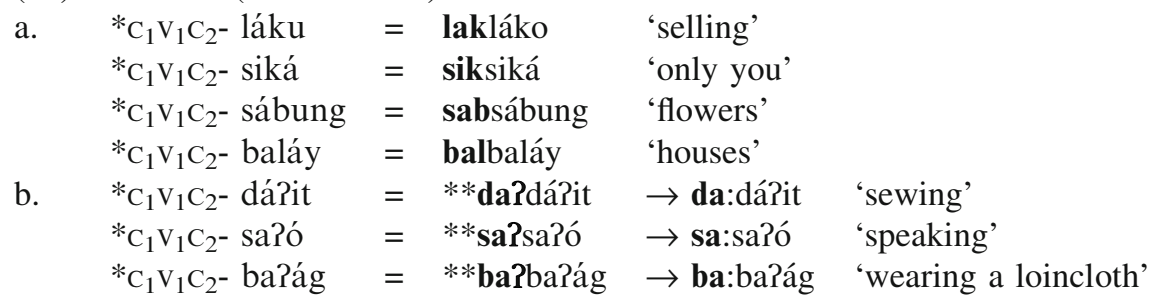

\subsubsection{Khinina-ang Bontok human noun plurals}

In order to understand the nature of the abductive innovations that have taken place with reference to Bontok human noun pluralization, it is necessary to review some of the phonological processes which operate following derivation by any vowel final prefix, in particular medial vowel syncope and metathesis.

All the bases listed in (21) are disyllabic, having an unstressed schwa (or a vowel which developed from schwa (as in the case of /tulú/ <*təlú 'three') in the first syllable. The ultimate syllable of each base carries primary stress. In (21)a, medial vowel syncope occurs following prefixation. In (21)b, in which the bases begin with a glottal stop, medial vowel syncope results in an unallowable glottal stop initial consonant cluster which is resolved by metathesizing the consonants.

(21) Khinina-ang Bontok ${ }^{7}$

\begin{tabular}{|c|c|c|c|c|c|c|}
\hline$*_{\text {na- }}$ & bəláy & $\rightarrow$ & & & nabláy & 'tired' \\
\hline *ka- & dəwá & $\rightarrow$ & & & kadwá & 'half' \\
\hline$* \mathrm{CV}-$ & tulú & $\rightarrow$ & & & tutlú & 'do three at a time' \\
\hline$*$ na- & Pəmə́s & $\rightarrow$ & **na-Pmə́s & $\rightarrow$ & nam?ás & 'bathed' \\
\hline *ka- & Pəpát & $\rightarrow$ & **ka-?pát & $\rightarrow$ & kap?át & 'quarter' \\
\hline$* \mathrm{CV}-$ & Pəpát & $\rightarrow$ & **2ə-Ppát & $\rightarrow$ & Pəp?át & 'do four at a time' \\
\hline *?i- & ใəməs & $\rightarrow$ & **?i-Pmð́s & $\rightarrow$ & Pimpəs & 'bathe with' \\
\hline
\end{tabular}

Children, when developing their own grammars have various possible analyses available to them to account for the forms of plural human nouns. The first assumes that children have available to them the knowledge that human nouns can be pluralized with $\mathrm{C}_{1} \mathrm{~V}_{1^{-}}$, (sasaggún 'neighbors', gagayyóm 'friends', etc.) and that for forms with an unstressed initial schwa, the phonological processes exemplified above are productive and applicable. Since most human nouns begin with a glottal stop, this analysis can be stated simply as Hypothesis 1.

\footnotetext{
${ }^{7}$ All Khinina-ang Bontok forms from this point on are given in the phonemic transcription of the language as spoken fifty years ago. Today as a result of English education and borrowings from Ilokano and other languages, many of the allophonic variants of voiced stops /b, d, g/ and of /l/ have lost their conditioning factors, resulting in new phonemes $/ \mathrm{f}, \mathfrak{f}, \mathrm{k}^{\mathrm{h}} /$ and $/ \mathrm{r} /$, inclusion of which obscures the reduplicative processes (see Reid 2005).
} 
Abductive Innovation: Hypothesis 1

"Human nouns beginning with glottal stop are pluralized by reduplicating $\mathrm{C}_{1} \mathrm{~V}_{1}$-."

While this analysis with application of the phonological rules would correctly produce the plural of 'sibling' (with unstressed initial schwa vowel), and several other forms (without unstressed initial schwa vowel), as in (22)a, it would incorrectly produce the forms in (22)b, forms which are all grammatical in closely related Kiangan Ifugao (Lambrecht 1978).

\section{(22) Khinina-ang Bontok}

\begin{tabular}{|c|c|c|c|}
\hline Potád & / Pət?ád & 'sibling' & / 'siblings' \\
\hline Píkit & / Piríkit & 'aunts' & / 'aunts' \\
\hline Palitá?u & / Ra?alitá?u & 'uncle' & / 'uncles' \\
\hline Pamá & / *RaPamá & 'father' & / 'fathers' \\
\hline Piná & / *Piriná & 'mother' & / 'mothers' \\
\hline Papú & / *Ra?apú & 'grandparent' & / 'grandparent' \\
\hline Ragí & / *PaPagí & 'kin (sG.)' & / 'kin (PL) \\
\hline
\end{tabular}

An alternate analysis, which by analogical extension correctly produces the appropriate plural forms for (22)b, is shown as Hypothesis 2. It assumes that the common form for 'siblings' is the result, not of reduplication, but of glottal stop insertion.

Abductive Innovation: Hypothesis 2

"Human nouns beginning with glottal stop and carrying stress on the second vowel, like Pətád 'sibling', are pluralized by infixing glottal stop before the final vowel of the singular form."

Deductive extension of this new analysis results in (23).

(23) Khinina-ang Bontok

$\begin{array}{llll}\text { Pamá } & \text { / Pam?á } & \text { 'father' } & \text { / 'fathers' } \\ \text { Piná } & \text { / Pin?á } & \text { 'mother' } & \text { / 'mothers' } \\ \text { Papú } & \text { / Pap?ú } & \text { 'grandparent' } & \text { / 'grandparents' } \\ \text { Pagí } & \text { / PagPí } & \text { 'kin (sG)' } & \text { / 'kin (PL)' } \\ \text { Panák / Pan?ák } & \text { 'child' } & \text { / 'children' } \\ \text { Pinád / PịPád } & \text { 'sister-in-law' } & \text { / 'sisters-in-law' }\end{array}$

It should be noted that medial vowel syncope in Khinina-ang Bontok only regularly occurs when the medial vowel is an unstressed schwa (or an unstressed vowel that has developed from schwa by vowel harmony). It typically never occurs when the medial unstressed vowel is other than schwa, e.g., ?i- + ?abðl > Piyabðl 'to weave s.t. into cloth', not *Pibßól; Pi- + Pamá > Piyamá 'uncle', not *?im?a, etc. In the singular forms of (23), none of the unstressed vowels is schwa, so one must assume that no reduplication with vowel syncope and metathesis has occurred, and that glottal stop has simply been infixed to form the plurals. 
An alternate specification of the environment for the insertion of glottal stop that accounts for all the forms in (23) is shown as Hypothesis 3.

Abductive Innovation: Hypothesis 3

"Human nouns beginning with glottal stop and carrying stress on the second vowel, like Ṗtád 'sibling', are pluralized by infixing glottal stop following the second consonant of the singular form."

That this environment is also possible is evidenced by the alternate plurals of 'spouse' given in (24)a. The former was recorded from a language assistant (Pakoran Catay) in 1960, while the latter was recorded from his son (Attorney Luke Catay) in 2005. Both forms are probably current in the general population of the community. The stress condition is required to account for the plurals of 'aunt' and 'uncle', (24)b, neither of which has stress on the second vowel, and neither of which undergoes glottal stop insertion. They are pluralized by $\mathrm{C}_{1} \mathrm{~V}_{1^{-}}$- reduplication.

$\begin{array}{lllll}\text { a. } & \text { Pasáwa / Pasáw?a } & \text { 'spouse' } & \text { / 'spouses' } \\ & \text { Pasáwa } & \text { / Pas?áwa } & \text { 'spouse' } & \text { / 'spouses' } \\ \text { b. Píkit } & \text { / Pi?́kit } & \text { 'aunt' } & \text { / 'aunts' } \\ & \text { Palitá?u } & \text { / Pa?alitá?u } & \text { 'uncle' } & \text { / ' 'uncles' }\end{array}$

\subsubsection{Khinina-ang Bontok human age-group and descriptive noun plurals}

In Bontok, there is a small subclass of human age-group and descriptive nouns which are unique in that unlike other nouns in the language they are derived for both singular and plural number. Historically, it can be shown that the singular forms were derived with $\mathrm{C}_{1} \mathrm{~V}_{1} \mathrm{C}_{2}$ - reduplication and the plural forms by $\mathrm{C}_{1} \mathrm{~V}_{1^{-}}$- reduplication. The singular forms of human age-group nouns all have human nouns of the type discussed above as their base. The sense of the $\mathrm{C}_{1} \mathrm{~V}_{1} \mathrm{C}_{2}$ - reduplication by which they are derived seems to be 'similitude', that is, a married man, whether or not he has children is perceived as being like a parent.

$$
\begin{aligned}
& \text { Khinina-ang Bontok } \\
& \text { Panák / Pan?anák 'child (offspring)' / 'child (young person)' } \\
& \text { Pụá / Pụ?uná 'child' (age)' / 'child (young person)' } \\
& \text { Pamá / Pam?amá 'father' / 'married man, typically a parent' } \\
& \text { Piná / Pin?iná 'mother' / 'married woman, typically a parent' } \\
& \text { Papú / Pap?apú 'grandparent' / 'old person, typically a grandparent' }
\end{aligned}
$$

$\mathrm{C}_{1} \mathrm{~V}_{1} \mathrm{C}_{2}$ - reduplication with this sense is not unique to Bontok. Similar forms are found in several other languages of the northern Philippines, as well as in Taiwan. Lambrecht (1978) records Kiangan Ifugao Pam Pamá 'old man', and Pin?iná 'old woman', with plural forms reduplicated with $\mathrm{C}_{1} \mathrm{~V}_{1^{-}}$, ?a Pam?amá 'old men' and Pỉin?ina' 'old women'. Vanoverbergh (1972) records Isneg Pan?ana? 'child' and la Plakay 'old man', with the latter form reduplicated as lala?lakay 'old men', 
and Oates and Oates (1955) record Central Cagayan Agta balbalaataang 'adolescent' (cf. balataang 'unmarried girl, virgin'). For Siraya, one of the Formosan languages, Ferrell (1969) lists amama 'man/male' and inina 'woman', and for Thao, Blust (2003) records azazak 'child'.

Three non-glottal stop initial human nouns occur with the same pattern in Khinina-ang Bontok. The base form of (26)a, although found in the language with the meaning given, is probably a borrowing of Ilokano baru' 'young unmarried man'. Similarly (26)b, is based on a borrowing of Ilokano balásang 'young unmarried woman', a form which does not occur as such in Bontok. Both of the Bontok forms have $\mathrm{C}_{1} \mathrm{~V}_{1} \mathrm{C}_{2}$ - reduplication with regular substitution of the medial liquid with glottal stop and metathesis (see Sect. 2.1). The base for the inherited term for young unmarried woman, shown as (26)c, does not occur as such in the language either. It apparently developed from an earlier *ma-dəkít 'beautiful', ${ }^{*}$ with vowel syncope (*madkit) and assimilation (maggit).

a. balú / bab?alú 'new' / 'young unmarried man'

b. (balásạ) / bab?alásan _- / 'young unmarried woman'

c. (maggit) / magmaggit _- / 'young unmarried woman'

Of these forms, only (26)c carries a simple $\mathrm{C}_{1} \mathrm{~V}_{1}$ - reduplication when pluralized, the others have reduplication plus gemination of the second consonant of the base, as in (27), implying a new analysis and subsequent extension based on (27)c, in which the second consonant of the base itself is geminated, but has been analyzed as a necessary part of the plural of this small set of forms. No other explanation is available for the gemination of the plural forms in (27)a-b.

\section{(27) Khinina-ang Bontok}

a. babPalú / baballú 'young unmarried man' / 'young unmarried men'

b. bab?alásạ / baballásay 'young unmarried woman' / young unmarried women c. magmaggit / mamaggit 'young unmarried woman' / young unmarried women

The plurals of the glottal stop initial forms in (25) require a different set of explanations. There is no evidence that they are formed by $\mathrm{C}_{1} \mathrm{~V}_{1}$ - reduplication, as in the equivalent Kiangan Ifugao forms. The forms in (28)a suggest that the glottal stop infixation rule before the final vowel (discussed above as abductive innovation: hypothesis 2), has been extended also to the plurals of human age-group terms, but with an additional innovation which deleted the glottal stop which was the initial consonant of the unreduplicated base, or "shift glottal stop from the beginning of the second syllable to the beginning of the final syllable of the word'.

\footnotetext{
$\overline{8}$ This reconstruction has reflexes in a number of Philippine languages, e.g., Tagalog dikit 'radiant beauty' (Panganiban 1966), Kiangan Ifugao madíkit 'beautiful' and Northern Alta mədí Pet / məddi?ít 'young woman / young women'.
} 
(28) Khinina-ang Bontok

\begin{tabular}{|c|c|c|c|}
\hline Pan?anák & $/ \mathrm{Pa}$ & 'child' & / $\mathrm{ch}$ \\
\hline & & 'ch & p)' \\
\hline & $/ ?$ & 'm & group)' \\
\hline & $/ \mathrm{Pi}$ & man' & ge-grou \\
\hline ? & / Panap?ú & ld person' & / 'old people (age-group)' \\
\hline
\end{tabular}

Example (28)b, however, appears to be irregular, in that given the preceding forms in this set, one would expect *?apap?ú, but this is a non-occurring form. Instead, in addition to the infixation of glottal stop before the final vowel, an $\langle a n>$ infix occurs immediately after the initial glottal stop. The development of this fixed segment infix is apparently based on a reinterpretation of the reduplicative $-\mathrm{V}_{1} \mathrm{C}_{2^{-}}$ segments in the word for child. In Bontok, this analysis has not spread to the other members of the set, although in other languages, such as Balangao (see below) it has.

In Khinina-ang Bontok $\langle a n>$ 'plural' has spread also to a small set of descriptive nouns, which like human age-group terms, are obligatorily marked for number. These terms are not only descriptive of human beings, but of non-humans as well. Descriptive nouns such as these in related languages are not marked for number, but do have $\mathrm{C}_{1} \mathrm{~V}_{1} \mathrm{C}_{2}$ - reduplication functioning as comparative degree (Shetler 1976, p. 95). Note also that the plural of the term for 'big' also geminates the second consonant of the base, following the pattern seen in the human age-group plurals in (27) $\mathrm{a}-\mathrm{b}$.

(29) Khinina-ang Bontok

\begin{tabular}{|c|c|c|c|}
\hline íg & 1 & & 11 \\
\hline andú & $/ \mathrm{R}<\mathrm{a}$ & 'long, tall (person, object) SG' & , tall \\
\hline kda & $/ \mathrm{d}<\mathrm{a}$ & 'big (person, object) s & $\begin{array}{l}\text { / 'big } \\
\text { (person, object) PL' }\end{array}$ \\
\hline & $1,2<$ & 'short (person, object) & $\begin{array}{l}\text { /'short } \\
\text { (person, object }\end{array}$ \\
\hline
\end{tabular}

In Balangao, a similar innovation has developed. In this language, the infix $<a n>$ occurs not only in age-group terms (30)a, but has developed as a marker of plurals in various human nouns as well, (30)b. And a further development has taken place. In bases in which the initial vowel is $i$ (such as 'woman' and 'companion'), the infix is $<i n>$ not $<a n>$. And as shown from the alternative forms in (31), a gender distinction is being innovated, with $<i n>$ spreading to feminine human nouns, 'women' and 'young women', which do not have initial $i$ vowels, and $<a n>$ appears as an alternate to a reduplicative form in the term for 'men'. 
(30) Balangao (Shetler 1976)

$\begin{array}{llll}\text { a. Pam?ama } & \text { / }<<\text { an }>\text { am?ama } & \text { 'man' 'men' } \\ \text { babalasang } & / \mathrm{b}<\mathrm{an}>\text { abalasang } & \text { 'young woman' } & \text { / 'young women' } \\ \text { babulu } & / \mathrm{b}<\mathrm{an}>\text { abulu } & \text { 'young man' } & \text { / 'young men' } \\ \text { Pin?ina } & / \mathrm{P}<\text { in }>\text { in?ina } & \text { 'woman' } & \text { / 'women' }\end{array}$

\begin{tabular}{|c|c|c|c|c|c|}
\hline Papo & / *?ap?o & $>$ & P<an $>$ ap?o & 'grandparent' & / 'grandparents' \\
\hline Ragi & / *2agii & $>$ & P<an>ag?i & 'sibling' & / 'siblings' \\
\hline Pama & / *2amma & $>$ & $\mathrm{P}<\mathrm{an}>\mathrm{amma}$ & 'father' & I 'fathers' \\
\hline Piba & / *Pib?a & $>$ & $\mathrm{P}<\mathrm{in}>\mathrm{ib} \mathrm{a}$ & 'companion' & / 'companions' \\
\hline ?ina & / *Pinna & $>$ & $?<$ in $>$ inna & 'mother' & / 'mothers' \\
\hline
\end{tabular}

(31) Balangao (Shetler 1976)

$\begin{array}{llll}\text { a. buba?e } & \text { / binuba?e } & \text { 'woman' / 'women' } \\ \text { b. banabalasang } & \sim \text { binabalasang } & \text { 'young women' } & \\ & \text { lallala?e } & \sim \text { lanla?e } & \text { 'men' }\end{array}$

\section{Conclusion}

This paper has focused on the diachronic development of $\mathrm{C}_{1} \mathrm{~V}_{1^{-}}$, a very common reduplicative affix in Austronesian languages, with a wide range of functions, verbal as well as nominal. I have claimed that in all cases it is one of the end points of the reduction and grammaticalization processes that affect reduplication, and that the frequent appearance of $\mathrm{C}_{1} a$ - fixed segment reduplication is not the source of $\mathrm{C}_{1} \mathrm{~V}_{1^{-}}$, but is one further step in grammaticalization, motivated analogically by the frequent appearance of $a$ as the first vowel in reduplicated bases, and by the frequency of a large number of fixed CV- prefixes with an $a$ vowel, such as $\mathrm{pa-}, \mathrm{ma}^{-}, \mathrm{ka-}, \mathrm{ta}-\mathrm{s} \mathrm{s}^{-}$, etc., which often occupy the same position relative to the base as $\mathrm{C}_{1} \mathrm{~V}_{1}$ - reduplication. Given the strong analogical base for fixed-vowel reduplicants, the probability that forms such as $\mathrm{C}_{1} a$ - are reconstructible to Proto-Austronesian, with one, let alone three distinct functions as proposed by Blust (1998) is highly unlikely, and any attempt to reconstruct a reduplicative process whether with an iconic or some post-iconic sense is methodologically unwise. The forms (and their functions) are far more likely to be the results of convergent development.

Various formal and functional developments have been outlined which suggest that $\mathrm{C}_{1} \mathrm{~V}_{1}$ - ultimately has its source in full reduplication with natural paths of semantic change from iconic to non-iconic functions, such as human noun pluralization. Formal developments from simple reduplication of the first two segments of a form, to gemination, to fixed vowel $\mathrm{C}_{1} a$ - reduplicative affixes, and other nonreduplicative, fixed segment affixation, such as $\langle$ ? $>$ and $<$ an $>$ infixation have been demonstrated. The paper has highlighted the role of new learners of a language, typically children, but not excluding adults, in innovating new forms based on reduplicative processes. Because of the interaction of reduplication with 
phonological rules in a language, such as vowel syncope, ambiguities often develop, resulting in new analyses of old forms, with subsequent spread of the new analyses to forms which would not otherwise have been candidates for the change. These new analyses are considered here to be abductive changes, with the analogical extensions seen as deductive developments. Since nothing is changed when a new analysis is made, it can only be recognized when it is extended to forms which would not have been affected by the earlier analysis. It is from the deductive processes that the abductive analyses become apparent.

Where there is no standard language which can hinder the acceptance of new analyses, such as with the minority languages of the northern Philippines, language change appears to be quite rapid. Among closely related languages, such as Bontok, Kankanay, Balangao and Ifugao, considerable differences are apparent in the formation of human noun plurals. And even in Bontok, over two generations in a period of less than 50 years, several changes have become apparent. One such change was mentioned in Sect. 4.2.2. Another change appears to be on-going, with some younger speakers now reconstituting plural forms with $\mathrm{C}_{1} \mathrm{~V}_{1^{-}}$reduplication, but derived not from older singular forms, but with forms that have already been infixed with glottal stop (as in (23) and (28)). Other speakers alternate between the two, as in (32).

\begin{tabular}{|c|c|c|c|}
\hline \multicolumn{4}{|c|}{ Khinina-ang Bontok } \\
\hline Pam?á & $\sim$ & Pa?amPá & 'fathers' \\
\hline PinPá & $\sim$ & Pißin?á & 'mothers' \\
\hline Pap?ú & $\sim$ & PaPap?ú & 'grandparents' \\
\hline Pag?í & $\sim$ & PaPag?í & 'kin (pl.)' \\
\hline PanPák & $\sim$ & Pa?an?ák & 'children' \\
\hline Punuy?a & & PuPunū?a & 'children' \\
\hline
\end{tabular}

It is possible that changes of this sort are not the result of new analyses, but are the result of contact with languages, such as Ifugao, in which $\mathrm{C}_{1} \mathrm{~V}_{1}$ - reduplication of glottal stop initial forms is still widespread.

\section{References}

Andersen, H. (1973). Abductive and deductive change. Language and Linguistics, 49, 765-793.

Andersen, H. (2001). Actualization and the (uni)directionality of change. In H. Andersen (Ed.), Actualization (pp. 225-248). Amsterdam and Philadelphia: John Benjamins.

Andersen, H. (2006). Grammation, regrammation, and degrammation: Tense loss in Russian. Diachronica, 23(2), 231-258.

Benton, R. A. (1974-1975). Pluralization in Ilokano: The realization of form and meaning. Te Reo, 17-18, 3-9.

Blevins, J. (2004). Evolutionary phonology: The emergence of sound patterns. Cambridge: Cambridge University Press.

Blevins, J. (2005). The role of phonological predictability in sound change: Privileged reduction in Oceanic reduplicated substrings. Oceanic Linguistics, 44(2), 517-526.

Blust, R. (1998). Ca- reduplication and Proto-Austronesian grammar. Oceanic Linguistics, 37(1), $29-64$.

Blust, R. (1999). Squib: A note on covert structure: Ca- reduplication in Amis. Oceanic Linguistics, 38(1), $168-174$. 
Blust, R. (2003). Thao dictionary [Language and Linguistics Monograph Series Number A5]. Taipei: Institute of Linguistics (Preparatory Office), Academia Sinica.

Blust, R. (2007). Disyllabic attractors and anti-antigemination in Austronesian sound change. Phonology, 24, 1-36.

Bybee, J. L., Perkins R. D., \& Pagliuca, W. (1994). The evolution of grammar: Tense, aspect and modality in the languages of the world. Chicago, London: University of Chicago Press.

Deutscher, G. (2002). On the misuse of the notion of "Abduction" in linguistics. Journal of Linguistics, $38,469-485$.

Ferrell, R. (1969). Taiwan aboriginal groups: Problems in culture and linguistic classification [Institute of Ethnology, Academia Sinica, Monograph No. 17]. Taipei: Academia Sinica.

Fischer, O. (2007). Morphosyntactic change: Functional and formal perspectives [Oxford Surveys in Syntax and Morphology]. Oxford: Oxford University Press.

Hsin, A. (1996). Noun phrase structure and focus marking in Kavalan. Tsing Hua Journal of Chinese Studies, New Series, 26(3), 323-364.

Hurch, B., \& Mattes V. (2005). Über die Entstehung von partieller Reduplikation. In G. Fenk-Oczlon \& C. Winkler (Eds.), Sprache und Natürlichkeit (pp. 137-156). Gedenkband für Willi Mayerthaler. Tübingen: Narr.

Lambrecht, F. H. (1978). Ifugaw-English dictionary. Baguio City, Philippines: The Catholic Bishop Apostolic of the Mountain Province.

Lopez, C. (1949). Reduplication in Tagalog (revised edition). Manila: Bureau of Printing.

Mattes, V. (2007). Types of reduplication: A case study of Bikol. Ph.D. dissertation, Karl-FranzensUniversität, Graz, Austria.

Newell, L. E. (1993). Batad Ifugao dictionary with ethnographic notes [Linguistic Society of the Philippines Special Monograph Issue, Number 33]. Manila: Linguistic Society of the Philippines.

Niepokuj, M. (1997). The development of verbal reduplication in Indo-European [Journal of IndoEuropean Studies Monograph 24]. Washington: Institute for the Study of Man.

Oates, W. J., \& Lynette F. O. (1955). Central Cagayan Negrito vocabulary. Manila: The Summer Institute of Linguistics and the Institute of National Language of the Department of Education.

Odden, D. (1988). Anti anti-gemination and the OCP. Linguistic Inquiry, 19, 451-475.

Panganiban, J. V. (1966). Talahuluganang: Pilipino-Ingles. Manila: Kawanihan ng Palimbagan.

Reid, L. A. (1976). Bontok-English dictionary, with English Bontok finder list. Canberra: Pacific Linguistics C-36.

Reid, L. A. (1992). On the development of the aspect system in some Philippine languages. Oceanic Linguistics, 31(1), 65-91.

Reid, L. A. (2005). A cross-generational view of contact-related phenomena in a Philippine language: Phonology. In S. Quakenbush \& D. Dayag (Eds.), Sociolinguistics and language education in the Philippines and beyond: Festschrift in honor of Ma. Lourdes S. Bautista. Manila: Linguistic Society of the Philippines and the Summer Institute of Linguistics.

Reid, L. A. (2006). Human noun pluralization in Northern Luzon languages. In H. Y. Chang, L. M. Huang, \& D. Ho (Eds.), Streams converging into an ocean: Festschrift in honor of Professor Paul Li on his 70th birthday (pp. 49-70). Taipei: Academia Sinica.

Reid, L. A. (2007). Another look at the marking of plural personal noun constructions in Austronesian languages. Oceanic Linguistics, 46(1), 232-252.

Rubino, C. (2000). Ilocano dictionary and grammar [PALI Language Texts]. Honolulu: University of Hawai'i Press.

Rubino, C. (2006). Intensive Tausug: A pedagogical grammar of the language of Jolo. Kensington: Dunwoody Press.

Schachter, P. (1987). Tagalog. In B. Comrie (Ed.), The world's major languages (Chap. 41). New York: Oxford University Press.

Shetler, J. (1976). Notes on Balangao grammar [Language Data: Asian-Pacific Series, No. 9]. Huntington Beach: Summer Institute of Linguistics.

Thurgood, E. (1997). Bontok reduplication and prosodic templates. Oceanic Linguistics, 36(1), $135-148$.

Topping, D. M., Ogo, P. M., \& Dungca, B. C. (1975). Chamorro-English dictionary [PALI Language Texts: Micronesia]. Honolulu: University Press of Hawai'i.

Vanoverbergh, M. (1955). Iloko grammar. Baguio City: Catholic School Press.

Vanoverbergh, M. (1972). Isneg-English vocabulary [Oceanic Linguistics Special Publication No. 11]. Honolulu: University Press of Hawai'i. 
Zeitoun, E., \& Wu C.-H. (2006). An overview of reduplication in Formosan languages. In H. Y. Chang, L. M. Huang, \& D. Ho (Eds.), Streams converging into an ocean: Festschrift in honor of Professor Paul Li on his 70th birthday (pp. 97-142). Taipei: Academia Sinica.

Zorc, R. D. (1979). On the development of contrastive word accent: Pangasinan, a case in point. In N. D. Liem (Ed.), Southeast Asian linguistic studies (Vol. 3, pp. 241-258). Canberra: Department of Linguistics, Research School of Pacific Studies, Australian National University. 